University of Nebraska - Lincoln

DigitalCommons@University of Nebraska - Lincoln

2020

\title{
Evaluation of Green Grass as a Feed Ingredient in Beef Finishing \\ Rations and Impact on Cattle Performance, Carcass \\ Characteristics, and Fatty Acid Profiles in Meat
}

Mitchell M. Norman

Nicolas A. Bland

Bradley B. Boyd

Briana B. Conroy

Andrea K. Watson

See next page for additional authors

Follow this and additional works at: https://digitalcommons.unl.edu/animalscinbcr

Part of the Large or Food Animal and Equine Medicine Commons, Meat Science Commons, and the Veterinary Preventive Medicine, Epidemiology, and Public Health Commons

This Article is brought to you for free and open access by the Animal Science Department at DigitalCommons@University of Nebraska - Lincoln. It has been accepted for inclusion in Nebraska Beef Cattle Reports by an authorized administrator of DigitalCommons@University of Nebraska - Lincoln. 


\section{Authors}

Mitchell M. Norman, Nicolas A. Bland, Bradley B. Boyd, Briana B. Conroy, Andrea K. Watson, Galen E. Erickson, and Chris Calkins 


\section{Evaluation of Green Grass as a Feed Ingredient in Beef Finishing Rations and Impact on Cattle Performance, Carcass Characteristics, and Fatty Acid Profiles in Meat}

\author{
Mitchell M. Norman \\ Nicolas A. Bland \\ Bradley B. Boyd \\ Brianna B. Conroy \\ Andrea K. Watson \\ Galen E. Erickson \\ Chris R. Calkins
}

\section{Summary with Implications}

A finishing study utilizing 240 crossbred steers (initial $B W=750 \pm 52$ lb.) evaluated the performance, carcass characteristic and fatty acid profiles from finishing steers fed four inclusions (0, 10, 20, 30 \% DM basis) of Green Grass. There were no differences in weights, gain or carcass traits. Dry matter intake tended to linearly increase as Green Grass inclusion increased in the diet. Steers fed Green Grass had greater F:G, and steers fed $30 \%$ Green Grass had a lower marbling score. A linear increase in alpha linolenic acid, poly-unsaturated fatty acids, transunsaturated unsaturated fatty acids, and omega-3 fatty acids was observed in steak samples from steers fed increasing inclusion of Green Grass. Including up to $20 \%$ inclusion of Green Grass on a DM basis in finishing steer diets appears to have no effect on performance or carcass characteristics. Feeding Green Grass linearly improves omega-3 fatty acid concentration in meat.

\section{Introduction}

With human health studies showing benefits from consuming omega-3 fatty acids, there is interest in increasing the amount of omega-3 fatty acids in beef, which typically have small amounts of polyunsaturated fatty acids (PUFAs). Through a process called biohydrogenation, ruminant microbes convert dietary unsaturated fatty acids into more saturated mono-unsaturated fatty acids or completely saturated fatty acids. Research was conduct-

(c) The Board Regents of the University of Nebraska. All rights reserved. ed to determine if increasing omega-3 fatty acids in ruminant diets using a Korean feed product called Green Grass (Sunseo Omega Inc.; Chungcheongbuk-do, Korea) would alter the fatty acid profile in beef, cattle performance, or carcass characteristics.

\section{Procedure}

A 203-d finishing study was conducted at the Panhandle Research and Extension Center (PREC) feedlot in Scottsbluff, NE. Two hundred forty crossbred steers (initial $\mathrm{BW}=750 \pm 52 \mathrm{lb}$ ) were utilized. Twelve days prior to the initiation of the trial, steers were penned in groups of 10 and fed a common receiving diet of $45 \%$ corn silage, $35 \%$ alfalfa hay, 15\% WDGS, and $5 \%$ supplement on DM basis. Steers were processed on d-10 with Bovi-Shield Gold 5way (Zoetis, Parsippany, NJ) Safeguard oral dewormer (Merck Animal Health, Desoto, KS) and given an electronic and panel tag ID ear tags. Steers were limit fed a common diet at $2 \%$ of BW for 5 days and weighed for 2 consecutive days at the beginning of the trial to account for gut fill and establish initial BW. Steers were blocked by initial BW $(n=3)$, stratified by day 0 BW, and assigned randomly to pen. Due to an uneven distribution of initial BW, replication 1 (40 hd) was assigned to block 1, replications 2,3 , and 4 (120 hd) were assigned to block 2 , and replications 5 and 6 ( $80 \mathrm{hd}$ ) were assigned to block 3 . Pens were assigned randomly to 1 of 4 treatments with 10 steers/ pen and 6 pens/treatment. Treatments increased inclusion of Green Grass product at $0,10,20$, and $30 \% \mathrm{DM}$, displacing dryrolled corn (DRC) in the diet (Table 1). The remaining diet consisted of $15 \%$ WDGS, 20 $\%$ corn silage, and $6 \%$ liquid supplement. Two supplements were used, supplement in the control diet supplied extra protein in the form of urea. Supplements were formulated to provide $30 \mathrm{~g} /$ ton Rumensin ${ }^{\circledR}$ (Elanco Animal Health, Greenfield, IN) and $8.8 \mathrm{~g} /$ ton Tylan $^{\circledR}$ (Elanco Animal Health, Greenfield, IN). Cattle were stepped up to their assigned diets over the course of 24 days starting on day 1 with 5 steps. As step up diets progressed, alfalfa hay and corn silage was displaced by the ratio of dry rolled corn and Green Grass product in each of the treatment diets. Each step did not exceed over a 10\% DM displacement of roughage by concentrate.

Cattle were implanted with a Revalor 200 implant (Merck Animal Health, DeSoto, KS), and revaccinated with Express 5-way (Boehringer Ingelheim Vetmedica, Inc., Duluth, GA) and Stand Guard pouron insecticide (Elanco Animal Health, Greenfield, IN) on day 30. Cattle were harvested at a commercial packing plant (J F O’Neil Packing Co., Omaha, Ne) over 3 harvest days (day 190, 199, 203) where hot carcass weight (HCW), and liver abscess rates were collected. Ribeye area, marbling score, and $12^{\text {th }}$ rib back fat were recorded after a 48 h chill. Final BW, average daily gain (ADG), Feed:Gain (F:G) were calculated from HCW at a $63 \%$ dressing percentage. Steak samples were collected by cutting a $1.5^{\text {" }}$ steak from the $5^{\text {th }}$ rib. Steak samples were transported to the University of Nebraska meat lab for fatty acid analysis. Data were analyzed using the MIXED procedure of SAS (SAS Inst. Inc., Cary, NC) as a randomized block design. Pen was used as the experimental unit while kill block nested within BW block were included in the model as fixed effects.

Over the course of the feeding period, 4 steers were removed due to death, health or lameness issues. These animals were removed from the statistical analysis by removal from those pen averages. Logistical difficulties resulted in a shortage of Green Grass product to feed at the end of the feeding period. On d 150-176, Green Grass 10, 20, and 30 diets, were dropped to 7.5\%, 15\%, 22.5\% Green Grass inclusion, respectively. On d 177-187, Green Grass 10, 20 , and 30 diets, were dropped to $5 \%, 7.5 \%$, $15 \%$ Green Grass inclusion, respectively. On d 188 through the remainder or the trial, Green Grass 10 and 20 were switched to the control diet, while Green Grass 30 was 
dropped to $7.5 \%$ Green Grass inclusion. On day 189 through the remainder of the trial, Green Grass 30 was switched to the control diet.

\section{Results}

\section{Performance and Carcass Characteristics}

There were no differences in initial body weight (BW), final BW, hot carcass weight (HCW), average daily gain (ADG), calculated yield grade, liver scores, or longissimus muscle $(\mathrm{LM})$ area $(P \geq 0.15)$ across all treatments (Table 2.). A linear increase ( $P=$ 0.04 ) in DMI was observed for steers fed increasing inclusions of Green Grass. A cubic response was observed, but was generally quadratic $(P=0.07)$ for $\mathrm{F}: \mathrm{G}$ as Green Grass inclusion increased. As inclusion of Green Grass increased, F:G increased from 6.80 to 7.16. Steers fed Green Grass had similar conversions of 7.19, 7.04, 7.25 for 10, 20, and $30 \%$ Green Grass, respectively. Steers fed $30 \%$ Green Grass had a lower marbling score of 430 (small 30) compared with steers fed 0, 10, $20 \%$ Green Grass which had marbling scores averaging 470 (small 70). Steers fed Green Grass had greater intakes and equivalent ADG resulting in poorer conversions suggesting Green Grass has a lower energy value relative to corn, which was expected. Interestingly, F:G increased but was relatively constant for 10 , 20 , or $30 \%$ inclusion. It is unclear whether altering the Green Grass inclusions from day 150 to 203 impacted performance, but some impacts were expected for the Green Grass replacing energy dense corn during the finishing period.

\section{Fatty Acid Profile Analysis}

As inclusion of Green Grass increased in the diet, a linear decrease $(P \leq 0.02)$ was observed for C12:0, C14: 1, C15:0, C16:1, C17:0, C17:1, C18:1, C20:3 $\omega 6$, and total $\omega 6$ (omega-6) in mg/100 g of lean tissue (Table 3, $P<0.05)$. A linear increase $(P \leq$ $0.01)$ was observed for concentrations of

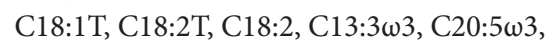
and $\mathrm{C} 22: 5 \mathrm{in} \mathrm{mg} / 100 \mathrm{~g}$ of lean tissue as Green Grass product inclusion in the diet increased. A quadratic effect $(P=0.06)$ was observed for mono-unsaturated fatty acid (MUFA) concentrations with an increase
Table 1. Diet Composition (DM basis) for finishing steers fed 4 inclusions of Green Grass product

\begin{tabular}{|c|c|c|c|c|}
\hline \multirow[b]{2}{*}{ Ingredient } & \multicolumn{4}{|c|}{ Treatment $^{1} \%$ Inclusion } \\
\hline & 0 & 10 & 20 & 30 \\
\hline Dry-rolled corn & 59 & 49 & 39 & 29 \\
\hline Wet Distillers Grains & 15 & 15 & 15 & 15 \\
\hline Green Grass ${ }^{1}$ & 0 & 10 & 20 & 30 \\
\hline Corn Silage & 20 & 20 & 20 & 20 \\
\hline Supplement ${ }^{2}$ & 6 & 6 & 6 & 6 \\
\hline $\mathrm{CP}, \%$ of sup & 46.0 & 7.0 & 7.0 & 7.0 \\
\hline $\mathrm{Ca}$ & 5.7 & 5.2 & 5.2 & 5.2 \\
\hline $\mathrm{P}$ & 0.05 & 0.09 & 0.09 & 0.09 \\
\hline Salt & 3.1 & 3.1 & 3.1 & 3.1 \\
\hline $\mathrm{K}$ & 2.6 & 3.2 & 3.2 & 3.2 \\
\hline Vitamin A, IU/lb & 10,820 & 10,820 & 10,820 & 10,820 \\
\hline \multicolumn{5}{|l|}{ Nutrient Composition ${ }^{3}, \%$} \\
\hline $\mathrm{DM}$ & 54.26 & 54.28 & 54.31 & 54.33 \\
\hline $\mathrm{CP}, \% \mathrm{DM}$ & 13.96 & 13.97 & 16.31 & 18.66 \\
\hline $\mathrm{ADF}, \% \mathrm{DM}$ & 10.26 & 12.46 & 14.65 & 16.85 \\
\hline $\mathrm{Ca}, \% \mathrm{DM}$ & 0.40 & 0.47 & 0.56 & 0.65 \\
\hline $\mathrm{P}, \% \mathrm{DM}$ & 0.45 & 0.51 & 0.58 & 0.64 \\
\hline $\mathrm{Mg}, \% \mathrm{DM}$ & 0.14 & 0.17 & 0.20 & 0.23 \\
\hline $\mathrm{K}, \% \mathrm{DM}$ & 0.81 & 0.91 & 0.96 & 1.02 \\
\hline $\mathrm{Na}, \% \mathrm{DM}$ & 0.03 & 0.04 & 0.06 & 0.07 \\
\hline $\mathrm{S}, \% \mathrm{DM}$ & 0.17 & 0.21 & 0.26 & 0.30 \\
\hline Fe PPM & 65.8 & 157.2 & 248.5 & 339.9 \\
\hline Zinc PPM & 26.8 & 32.0 & 37.8 & 43.6 \\
\hline $\mathrm{Cu}$ PPM & 2.9 & 6.1 & 9.2 & 12.4 \\
\hline Manganese PPM & 15.2 & 22.6 & 30.1 & 37.5 \\
\hline \multicolumn{5}{|l|}{ Fatty Acid Profile 3 , \% DM } \\
\hline C12:0 & 0.00 & 0.00 & 0.00 & 0.00 \\
\hline C14:0 & 0.00 & 0.00 & 0.00 & 0.00 \\
\hline $\mathrm{C} 16: 0$ & 0.62 & 0.66 & 0.70 & 0.73 \\
\hline $\mathrm{C} 16: 1$ & 0.00 & 0.01 & 0.01 & 0.02 \\
\hline C18:0 & 0.08 & 0.10 & 0.13 & 0.16 \\
\hline C18:1 & 1.05 & 1.18 & 1.31 & 1.44 \\
\hline $\mathrm{C} 18: 2$ & 2.33 & 2.28 & 2.22 & 2.17 \\
\hline $\mathrm{C} 18: 3$ & 0.11 & 0.31 & 0.52 & 0.73 \\
\hline C20:0 & 0.01 & 0.02 & 0.02 & 0.02 \\
\hline C20:1 & 0.01 & 0.02 & 0.02 & 0.02 \\
\hline C20:5 & 0.00 & 0.00 & 0.01 & 0.01 \\
\hline $\mathrm{C} 22: 0$ & 0.00 & 0.00 & 0.01 & 0.01 \\
\hline $\mathrm{C} 22: 6$ & 0.00 & 0.00 & 0.01 & 0.01 \\
\hline C24:0 & 0.01 & 0.01 & 0.01 & 0.01 \\
\hline Other & 0.18 & 0.22 & 0.27 & 0.32 \\
\hline Total FattyAcids & 4.40 & 4.82 & 5.23 & 5.65 \\
\hline
\end{tabular}

${ }^{1}$ Differences in dietary treatment were due to Green Grass (Sunseo Omega 3, Chungcheongbuk-do, Korea) inclusion $(0,10,20$, $30 \%$ of diet DM)

${ }^{2}$ Supplements were formulated to provide $30 \mathrm{~g} /$ ton Rumensin (Elanco, Greenfield, IN), $8.8 \mathrm{~g} /$ ton Tylan $^{\circ}$ (Elanco Animal Health, Greenfield, IN), $15500 \mathrm{IU} / \mathrm{lb}$ of dry feed, supplement in diet 0 provided protein in the form of urea

${ }^{3}$ Nutrient Compositions and fatty acid profiles were formulated from ingredient samples 
Table 2. Effect of increasing inclusion of Green Grass in cattle performance and carcass characteristics

\begin{tabular}{|c|c|c|c|c|c|c|c|c|}
\hline \multirow[b]{2}{*}{ Item } & \multicolumn{4}{|c|}{ Treatment $^{1}$} & \multirow[b]{2}{*}{ SEM } & \multicolumn{3}{|c|}{ Contrast } \\
\hline & 0 & 10 & 20 & 30 & & $\mathrm{~L}^{2}$ & $\mathrm{Q}^{3}$ & $\mathrm{C}^{4}$ \\
\hline \multicolumn{9}{|c|}{ Carcass adjusted Performance } \\
\hline Final BW, lb & 1505 & 1485 & 1507 & 1484 & 10.2 & 0.16 & 0.98 & 0.11 \\
\hline DMI, lb/d & $26.2^{\mathrm{a}}$ & $27.0^{\mathrm{ab}}$ & $27.1^{\mathrm{b}}$ & $27.0^{\mathrm{b}}$ & 0.29 & 0.04 & 0.16 & 0.78 \\
\hline \multicolumn{9}{|l|}{ Carcass characteristics } \\
\hline HCW, lb & 948 & 936 & 950 & 935 & 6.4 & 0.16 & 0.96 & 0.11 \\
\hline LM area, in $^{27}$ & 12.5 & 12.1 & 12.4 & 12.4 & 0.14 & 0.85 & 0.16 & 0.21 \\
\hline Fat depth, in. & $0.73^{\mathrm{ab}}$ & $0.70^{\mathrm{a}}$ & $0.78^{\mathrm{b}}$ & $0.70^{\mathrm{a}}$ & 0.025 & 0.88 & 0.33 & 0.02 \\
\hline
\end{tabular}

\footnotetext{
${ }^{1}$ Differences in dietary treatments were due to Green Grass (Sunseo Omega 3, Chungcheongbuk-do, Korea) inclusion (0, 10, 20, or 30 \% of diet DM).

${ }^{2} \mathrm{~L}=\mathrm{P}$-value for the linear response to Green Grass inclusion

${ }^{3} \mathrm{Q}=\mathrm{P}$-value for the quadratic response to Green Grass inclusion

${ }^{4} \mathrm{C}=\mathrm{P}$-value for the cubic response to Green Grass inclusion

${ }^{5}$ Analyzed as G:F, reciprocal of F:G

${ }^{6}$ Percent of corn feeding value calculated as percent different in G:F from control divided by incluc

${ }^{6}$ REA (rib eye area in ${ }^{2}$ )

${ }^{8}$ Calc. YG (calculated yield grade), Calculated as $2.5+\left(2.5 \times 12^{\text {th }}\right.$ rib fat, in $)+(0.2 \times 2.5(\mathrm{KPH}, \%))+(.0038 \times \mathrm{HCW}, \mathrm{lbs})-.\left(0.32 \times \mathrm{REA}\right.$, in $\left.{ }^{2}\right)$

${ }^{9} 400=$ Small $^{0}, 500=$ Modest $^{0}$

${ }^{\mathrm{ab}}$ Means in a row with different superscripts differ $(P<0.05)$.
}

as Green Grass increased in the diet from 0 to $20 \%$ inclusion, then a decrease with 30 Green Grass. The concentration of C18:3w3 and total $\omega 3$ (omega-3) fatty acids linearly increased $(P \leq 0.01)$, close to 4 times the amount compared to the control in $\mathrm{mg} / 100$ $\mathrm{g}$ of lean tissue. Poly-unsaturated fatty acids (PUFA), and trans-unsaturated fatty acids (Trans) concentrations also linearly increased $(P \leq 0.01)$ in $\mathrm{mg} / 100 \mathrm{~g}$ of lean tissue, as Green Grass inclusion increased in the diet. Concentrations of total $\omega 6$, and the ratio of $\omega 6: \omega 3$ linearly decreased $(P \leq$ $0.01)$ as Green Grass inclusion increased in the diet. A quadratic response $(P=$ 0.04 ) was observed for total fat $\%$ from the proximate analysis, with 10 and 20 Green Grass having greater \% fat within lean steak sample at $11.41 \%$ and $11.51 \%$ compared to 0 and 30 Green Grass at $10.96 \%$ and 10.43 $\%$ (Table 4.). The percent of moisture in steak samples from the proximate analysis had a quadratic response $(P=0.02)$, with
0 and 30 Green Grass with greater percent moisture in lean steak samples at $68.13 \%$ and $68.75 \%$, compared to 10 and 20 Green Grass at $67.76 \%$ and $67.71 \%$.The increase in concentration PUFA, total $\omega 3, \mathrm{C} 18: 3 \omega 3$ support the hypothesis that increasing the amount of dietary omega- 3 fatty acids from feeding Green Grass positively influences fatty acids deposited in the meat, with dramatic increases in $\omega 3$ (omega-3) fatty acids.

\section{Conclusion}

Steers fed Green Grass had greater intakes and equivalent ADG compared to control cattle resulting in poorer feed conversion; however, other cattle performance parameters and carcass characteristics were not affected as Green Grass inclusion in the diet increased up to $30 \%$ on DM basis. Steers fed $30 \%$ Green Grass had lower marbling scores; however, they had higher concentrations of PUFA, total $\omega 3$, and
C18:3w3. Displacing corn up to $30 \%$ on DM basis with Green Grass product does not affect gain, and improves the PUFA, total $\omega 3$, and C18:3 $\omega 3$ concentrations in the meat. More research is needed to determine the energy content and digestibility of Green Grass, and the significance of the change in $\omega 3$ fatty acid concentrations in the steaks.

Mitchell M. Norman, graduate student

Nicolas A. Bland, graduate student

Bradley B. Boyd, research technician

Briana B. Conroy, research technician

Andrea K. Watson, research assistant professor

Galen E. Erickson, professor, University of Nebraska-Lincoln Department of Animal Science, Lincoln NE

Chris R. Calkins, professor, University of Nebraska-Lincoln Department of Animal Science, Lincoln NE 
Table 3. Fatty acid profile of steak samples collected at the $5^{\text {th }}$ rib from steers fed increasing inclusion of Green Grass product in $\mathrm{mg} / 100 \mathrm{~g}$ of lean tissue (DM basis)

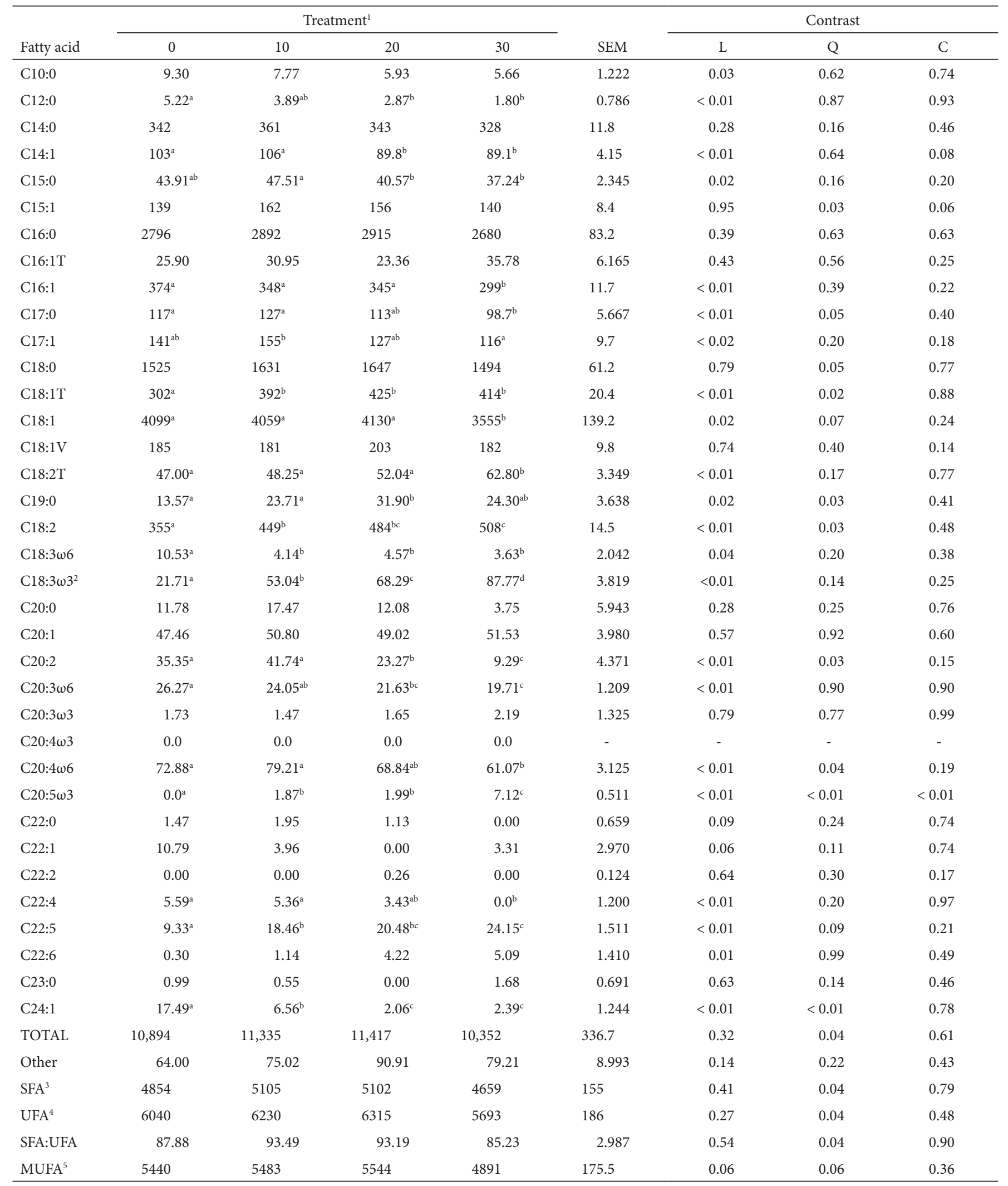


Table 3. Continued

\begin{tabular}{|c|c|c|c|c|c|c|c|c|}
\hline \multirow[b]{2}{*}{ Fatty acid } & \multicolumn{4}{|c|}{ Treatment $^{1}$} & \multirow[b]{2}{*}{ SEM } & \multicolumn{3}{|c|}{ Contrast } \\
\hline & 0 & 10 & 20 & 30 & & $\mathrm{~L}$ & Q & $\mathrm{C}$ \\
\hline PUFA $^{6}$ & $600^{\mathrm{a}}$ & $747^{\mathrm{b}}$ & $772^{\mathrm{b}}$ & $803^{c}$ & 22.1 & $<0.01$ & 0.02 & 0.21 \\
\hline$\omega 6^{8}$ & $112^{\mathrm{a}}$ & $110^{\mathrm{a}}$ & $97.2^{\mathrm{ab}}$ & $86.4^{\mathrm{b}}$ & 5.09 & $<0.01$ & 0.36 & 0.54 \\
\hline$\omega 3^{9}$ & $24.19^{\mathrm{a}}$ & $56.99^{\mathrm{b}}$ & $73.01^{c}$ & $97.30^{\mathrm{d}}$ & 4.320 & $<0.01$ & 0.34 & 0.22 \\
\hline
\end{tabular}

${ }^{1}$ Differences in dietary treatment were due to Green Grass (Sunseo Omega 3, Chungcheongbuk-do, Korea) inclusion (0,10, 20, 30 \% of diet DM)

Note: ${ }^{2} \mathrm{C} 18: 3 \omega 3=$ Alpha linolenic acid, ${ }^{3} \mathrm{SFA}=$ saturated fatty acids, ${ }^{4} \mathrm{UFA}=$ unsaturated fatty acids, ${ }^{5} \mathrm{MUFA}=$ monounsaturated fatty acids, ${ }^{6} \mathrm{PUFA}=$ polyunsaturated fatty acids, ${ }^{7}$ Trans $=$ Trans unsaturated fatty acids, ${ }^{8} \omega 6=$ total omega 6 fatty acids, ${ }^{9} \omega 3=$ total omega- 3 fatty acids

abcd Within row, means without a common superscript differ $(P<0.05)$

Table 4. Proximate analysis of lean steak samples from steers fed increasing inclusion of Green Grass product

\begin{tabular}{|c|c|c|c|c|c|c|c|c|}
\hline \multirow[b]{2}{*}{ Item } & \multicolumn{4}{|c|}{ Treatment ${ }^{1}$} & \multirow[b]{2}{*}{ SEM } & \multicolumn{3}{|c|}{ Contrast } \\
\hline & 0 & 10 & 20 & 30 & & $\mathrm{~L}^{2}$ & $\mathrm{Q}^{3}$ & $\mathrm{C}^{4}$ \\
\hline Fat, $\%$ & $10.96^{\mathrm{ab}}$ & $11.41^{\mathrm{ab}}$ & $11.51^{\mathrm{a}}$ & $10.43^{\mathrm{b}}$ & 0.340 & 0.34 & 0.04 & 0.60 \\
\hline Moisture, \% & $68.13^{\mathrm{ab}}$ & $67.76^{\mathrm{a}}$ & $67.71^{\mathrm{a}}$ & $68.75^{\mathrm{b}}$ & 0.260 & 0.20 & 0.02 & 0.57 \\
\hline
\end{tabular}

${ }^{1}$ Differences in dietary treatment were due to Green Grass inclusion $(0,10,20,30 \%$ of diet DM)

${ }^{2} \mathrm{~L}=\mathrm{P}$-value for the linear response to Green Grass inclusion

${ }^{3} \mathrm{Q}=\mathrm{P}$-value for the quadratic response to Green Grass inclusion

${ }^{4} \mathrm{C}=\mathrm{P}$-value for the cubic response to Green Grass inclusion 